\title{
Biosynthetic and Structural Studies of a Heavy Chain Disease Protein
}

\author{
Daniel Ein, Donald N. Buell, and John L. Fahey \\ From the Immunology Branch, National Cancer Institute, National Institutes of \\ Health, Bethesda, Maryland 20014
}

A B S T R ACT A new heavy chain disease protein $(\gamma \mathrm{HCD}-\mathrm{JM})$ has been characterized by antigenic and structural criteria. The protein belongs to the IgG3subclass and is closely related to Fc-fragment of G3immunoglobulins. The predominant $N$-terminal amino acid of this protein is glutamic acid in the uncyclized form, and that of another $\gamma \mathrm{HCD}$ is glycine.

Studies of the $N$-terminal peptides indicate that the $N$-terminal portion of the $\gamma 3$-heavy polypeptide chain is absent from the $\gamma \mathrm{HCD}-\mathrm{JM}$. These findings rule out a process of normal heavy chain initiation and a large deletion of the $\mathrm{Fd}$ region as being responsible for these two heavy chain disease proteins.

The $\gamma \mathrm{HCD}-\mathrm{JM}$ is a secretory product of cells from bone marrow as shown by studies of in vitro incorporation of amino acids $-{ }^{14} \mathrm{C}$. Bone marrow and lymph node have a population of lymphoplasmacytic cells which by immunofluorescence contain $\gamma$-heavy chain antigens in the absence of light chain antigens.

\section{INTRODUCTION}

Heavy chain disease is characterized by the presence of relatively homogeneous polypeptide chains that are immunochemically and structurally related to heavy polypeptide chains of normal immunoglobulins. In all previously reported cases (1-4) abnormal serum and/or urine protein has been related to $\gamma$-polypeptide chains. Franklin, Lownstein, Bigelow, and Meltizer (1) in their original description of the disease, and also Osserman and Takatsuki (2), showed that the characteristic anomalous immunoglobulin is, in fact, most closely related to the papain-produced Fc-fragment of normal IgG and does not correspond to the whole heavy polypeptide chain. The Fc-fragment contains the $\mathrm{COOH}$-terminal half of two identical $\gamma$-heavy chains (5). Since proteins are normally synthesized from the amino to the carboxyl terminus,

Received for publication 7 October 1968. the findings of a carboxyl terminal half of a heavy chain in this disease raises important questions about the mechanism of $\gamma$-heavy chain disease protein $(\gamma \mathrm{HCD})$ synthesis and the relation of this mechanism to the normal synthesis of immunoglobulins. Recognition of a new case of heavy chain disease $(\mathrm{JM})^{1}$ made possible studies at the cellular level which showed that this protein is a secretory product of cells and not a result of extracellular catabolism. It was determined that the cells synthesizing the anomalous heavy chain do not synthesize immunoglobulin light chains. Furthermore, structural studies were done to determine whether or not the normal $N$-terminal portion of the $\gamma$-heavy chain was present in the $\gamma \mathrm{HCD}$ molecules.

\section{METHODS}

Immunoelectrophoretic and Ouchterlony analytic technics and preparation of specific antisera have been previously described (6).

Purification of J. M. urinary paraprotein. Urine was first precipitated with $30 \%(\mathrm{v} / \mathrm{w})\left(\mathrm{NH}_{4}\right)_{2} \mathrm{SO}_{4}$ : The supernate was then brought to $50 \%\left(\mathrm{NH}_{4}\right)_{2} \mathrm{SO}_{4}(\mathrm{v} / \mathrm{w})$ saturation, the precipitate collected and desalted either by extensive dialysis against $0.14 \mathrm{M} \mathrm{NaCl}$ or by passage through a column of Sephadex G-25, eluting with $0.07 \mathrm{M} \mathrm{NaCl}$.

Geon-Pevikon block electrophoresis was then performed (6) and appropriate fractions were collected and concentrated by (Diaflo) ultrafiltration. DEAE-cellulose chromatography (Whatman DE-52 microgranular cellulose) was performed on fractions from block electrophoresis with a gradient elution from $0.05 \mathrm{M}$ to $0.3 \mathrm{~m}$ Tris $\mathrm{HCl}$ buffer, $\mathrm{pH}$ 8.0. The paraprotein-containing fraction $(100-150 \mathrm{mg})$ was then applied to a reverse-flow Sephadex G-200 column $(120 \times 4.5 \mathrm{~cm})$ and eluted with $0.2 \mathrm{M}$ Tris $\mathrm{HCl}-0.2 \mathrm{M} \mathrm{NaCl}$, pH 8.0 buffer.

Purity of the final product was assessed by immunoelectrophoresis and Ouchterlony analysis at a sample concentration of at least $20 \mathrm{mg} / \mathrm{ml}$. Several preparations were also tested in the ultracentrifuge and these showed only a single component.

${ }^{1}$ Zawadzki, Z. A., T. G. Benedek, D. Ein, and J. M. Easton. Rheumatoid arthritis terminating in heavy chain disease. Submitted for publication. 
Reduction and alkylation, tryptic digestions, and peptide maps were performed as described by Appella and Ein (7).

Preparation of Fc-fragment. A solution of purified IgG3-myeloma protein (Ben) was digested with papain by the method of Porter. Digestion proceeded at $37^{\circ} \mathrm{C}$ for only $2 \mathrm{hr}$ because of the lability of IgG3-myeloma proteins to papain digestion. Fc-fragment was separated from undigested protein and Fab-fragment by stepwise elution from DEAEcellulose (Whatman De-52 microgranular cellulose). Purity of the Fc-fragment was assessed by immunoelectrophoresis and Ouchterlony analysis at a concentration of $20 \mathrm{mg} / \mathrm{ml}$ and found to be free of contaminants by these criteria.

Immunofluorescence. Preparation of fluorescein- and rhodamine-conjugated antisera and staining of slides were performed as described by Finegold, Fahey, and Dutcher (8).

Biosynthesis. Biosynthetic studies were based on the procedure of Hochwald, Thorbecke, and Asofsky (9), as modified by Sanders et al. (10).

Ultracentrifugation. Ultracentrifugation was performed in the Spinco model $\mathrm{E}$ analytic ultracentrifuge with schlieren optics at a protein concentration of $5-10 \mathrm{mg} / \mathrm{ml}$ in $0.14 \mathrm{M}$ $\mathrm{NaCl}$. Sedimentation coefficient values reported here are not corrected to zero concentration or water.

Amino acid analysis. Aliquots of peptides were hydrolyzed with constant boiling of $6 \mathrm{~N} \mathrm{HCl}$ for $20 \mathrm{hr}$ at $108^{\circ} \mathrm{C}$. Whole reduced-alkylated protein was hydrolyzed in vacuo for $24 \mathrm{hr}$ at $108^{\circ} \mathrm{C}$ with $6 \mathrm{~N} \mathrm{HCl}$. Amino acid analysis was performed on a Spinco model 120C amino acid analyzer.

$\mathrm{NH}_{z}$-terminal amino acid. The $\mathrm{NH}_{2}$-terminal amino acids of the $\gamma \mathrm{HCD}-\mathrm{JM}$ protein and of another $\gamma \mathrm{HCD}$ (Craw) were determined by the method of Stark (11).
Isolation of $\mathrm{NH}_{2}$-terminal peptides. The $\gamma \mathrm{HCD}-\mathrm{JM}$ was acetylated by the method of Hood. ${ }^{2} 10 \mathrm{mg}$ was dissolved in 1 $\mathrm{ml}$ of $0.2 \mathrm{M} \mathrm{NH}_{4} \mathrm{HCO}_{3}$ and digested with Pronase at $37^{\circ} \mathrm{C}$ for $2 \mathrm{hr}$ with an enzyme substrate ratio of $1: 50$. Enzyme digests were applied to Dowex-50 $(\mathrm{H}+)$ columns and eluted with $15 \mathrm{ml}$ of water. A mixture of peptides was obtained This mixture was resolved into separate peptides by high voltage electrophoresis on paper, $\mathrm{pH}$ 6.5. The peptides were eluted from the paper with water and aliquots taken for amino acid analysis. Electrophoresis effectively separated these $N$-terminal peptides from carbohydrate-containing peptides that also pass through the Dowex column.

\section{RESULTS}

\section{(A) Characterization of J. M. paraprotein $(\gamma \mathrm{HCD}-\mathrm{JM})$}

1. Immunochemical studies. Immunoelectrophoresis of the patient's serum (Fig. 1) showed the serum to contain an anomalous arc of fast mobility near the antiserum trough. This arc was developed by a polyvalent anti-immunoglobulin serum and specific anti-IgG serum. Specific anti-kappa and anti-lambda sera did not show this arc. In addition, other immunoelectrophoretic tests of J. M. serum (not shown) with specific anti-IgA and anti-IgM sera did not show this arc. Normal IgG, $\operatorname{IgA}$, and $\operatorname{IgM}$ were detectable in the patient's serum in

${ }^{2}$ Hood, L. Unpublished method.

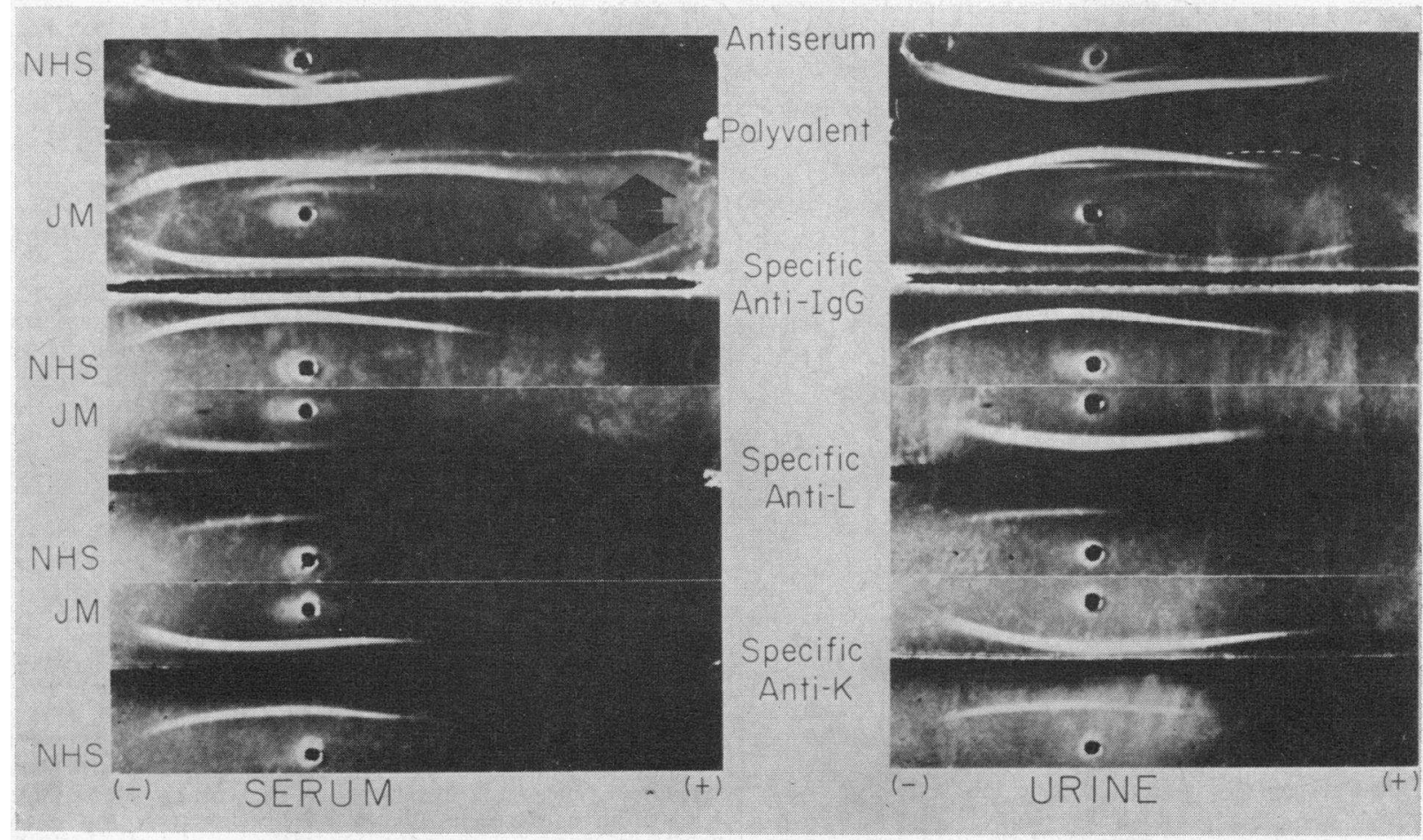

FIGURE 1 Immunoelectrophoresis of $J M$ serum and urine. $N H S$ refers to a normal human serum. The $\gamma \mathrm{HCD}-\mathrm{JM}$ arc (arrow) is developed with polyvalent antiserum and specific anti-IgG, but not with specific anti- $\kappa$ or anti- $\lambda$ serums. 
about normal amounts. These tests showed that the patient's serum contained an anomalous protein bearing $\gamma$-heavy chain determinants, but no kappa or lambda light chain determinants. This combination of findings is characteristic of heavy chain disease proteins. Similarly, immunoelectrophoretic tests of the patient's urine showed an anomalous arc that had a mobility identical to that of the serum paraprotein. The anomalous urinary protein also contained $\gamma$-heavy chain antigenic determinants, but no kappa or lambda light chain determinants. These findings showed that the urine, like the serum, contained a heavy chain disease protein. In addition, it can be seen that the urine contained normal IgG and $\operatorname{IgA}$, i.e., $\gamma$ and $\alpha$-determinants.

Ouchterlony tests of J. M. purified paraprotein were performed with 10 antisera specific for $\gamma$-heavy chains. These showed that the J. M. paraprotein contained antigenic determinants that it shared with normal $\operatorname{IgG}$ as well as with $G$ myeloma proteins and paraproteins from other cases of $\mathrm{H}$ chain disease. Tests with antisera specific for $\delta$-, $\alpha$-, and $\mu$-heavy polypeptide chains as well as specific anti-K and anti- $\lambda$ sera failed to give precipitin arcs with the J. M. paraprotein. These studies confirmed the serum studies, showing that the J. M. paraprotein contained $\gamma$-heavy chain antigenic determinants, but no determinants of other major immunoglobulin classes or of light chain types.

Several rabbit antisera made to whole normal human IgG were found to be especially useful for comparisons of the J. M. paraprotein with IgG and its subunits. Results of tests with one such antiserum are shown in Fig. 2. With the unabsorbed antiserum the J. M. paraprotein gave reactions of nonidentity with kappa and lambda light chains (Fig. $2 a$ ). The antiserum was rendered specific for $\gamma$-heavy polypeptide chains by absorption with kappa and lambda Bence Jones proteins. The J. M. paraprotein was shown to give a reaction of partial identity with normal IgG, of complete identity with normal $F c \gamma$, and of nonidentity with Faby, using the absorbed antiserum (Fig. $2 b$ ). Further absorption of this antiserum with normal $\mathrm{Fc}$ abolished the reactivity of the antiserum with the J. M. paraprotein, but not with normal IgG or Fab (Fig. 2 c). This antiserum also reacted with normal heavy chains (not illustrated) and therefore detected Fd-antigens. These tests showed that the J. M. paraprotein had antigenic determinants in common with the papain-produced Fc-fragment of IgG, but not with Fab- or Fd-fragments. This is consistent with

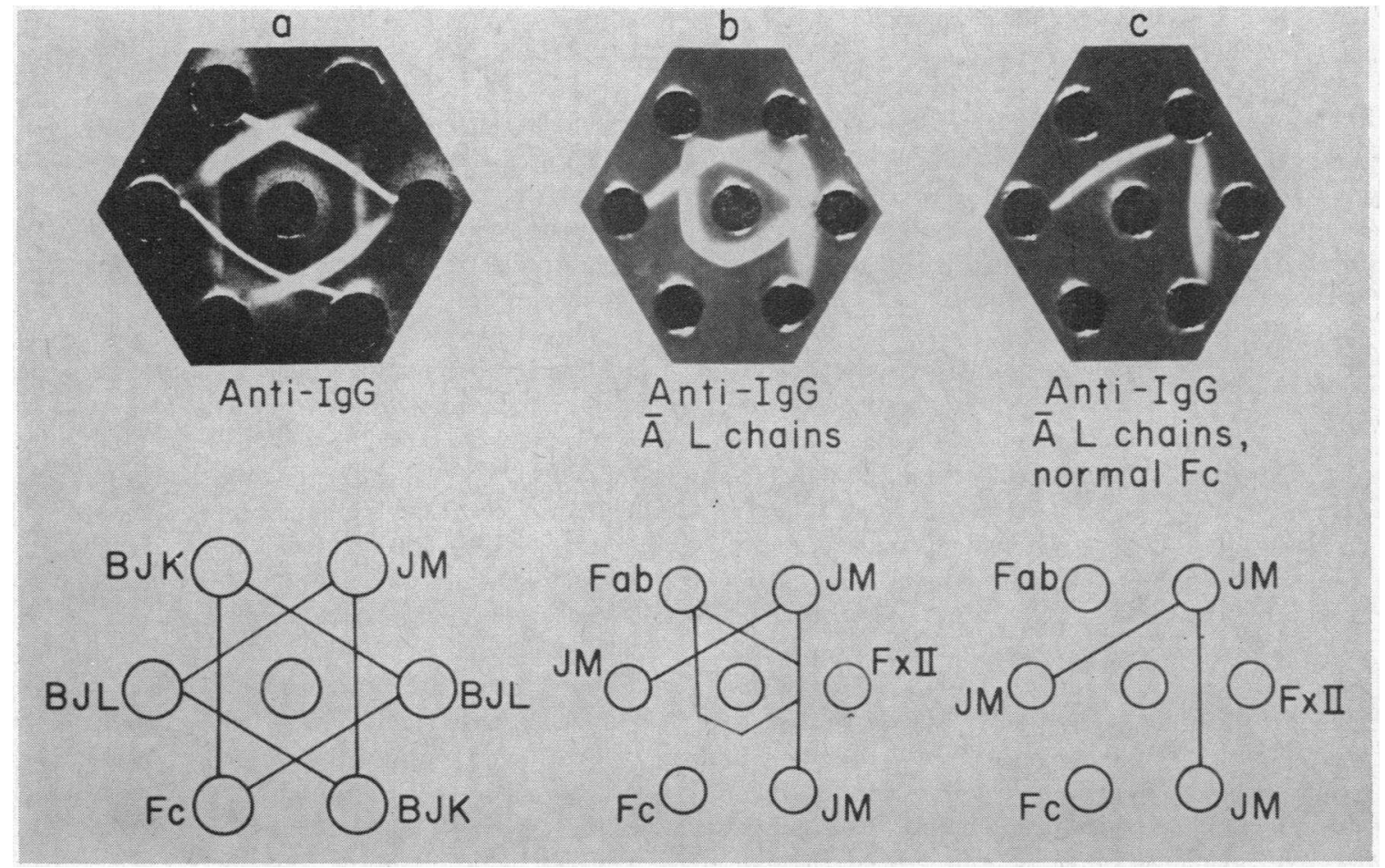

FIgURE 2 Comparison of $\gamma \mathrm{HCD}-\mathrm{JM}(J M)$ with IgG and its fragments. $2 a$, rabbit antiserum made to pooled normal human $\operatorname{IgG}$. $B J K, B J L$ are Bence Jones proteins (free light chains), types kappa or lambda. FxII, Cohn fraction II (Sylvana), containing pooled IgG molecules. $2 b$, antiserum absorbed with light chains. Note that $J M$ gives reactions of identity with $F c$, partial identity with FxII, and nonidentity with $F a b .2 c$, antiserum now absorbed with normal $F c$ no longer reacts with $J M$. 


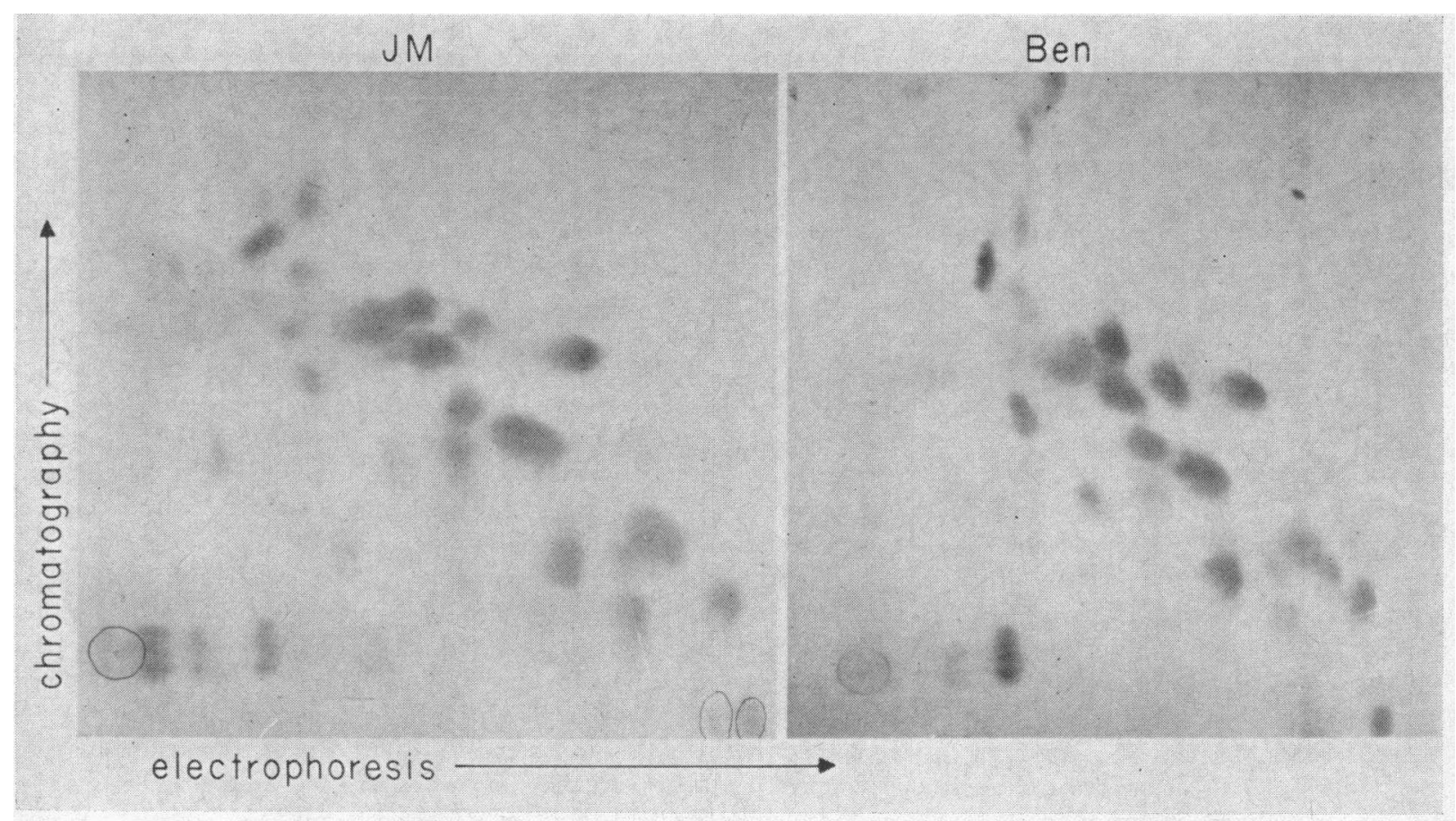

FIgURE 3 Peptide map comparison of $\gamma \mathrm{HCD}-\mathrm{JM}$ and the Fc-fragment of a myeloma protein of the same, i.e. G3, subclass $(B e n)$. Extra spots near the origin represent carbohydrate-containing peptides.

the findings that other $\mathrm{H}$ chain disease proteins are $\mathrm{Fc}$ like-fragments of heavy polypeptide chains (1-4).

2. Subclass and Gm tests. The $\gamma \mathrm{HCD}-\mathrm{JM}$ was shown to belong to the G3-subclass of IgG. Antigenic comparisons of the $\gamma \mathrm{HCD}-\mathrm{JM}$ with other $\mathrm{H}$ chain disease proteins were performed with an IgG3-specific antiserum made by immunizing a monkey with a G3-myeloma protein (12). The J. M. protein gave a reaction of identity with the $\mathrm{Zu} \mathrm{H}$ chain disease protein (also of G3-subclass), whereas no precipitin band was formed with the Craw $\mathrm{H}$ chain disease protein that belongs to the G1subclass.

Comparison of J. M. protein with an intact G3-myeloma protein was performed with a monkey antiserum which differentiates G1-, G2-, and G3-subclasses. $\gamma \mathrm{HCD}-J \mathrm{M}$ gives reactions of identity with normal Fcfragments but only partial identity with whole G3-immunoglobulin molecules. The J. M. protein apparently lacks some of the G3-determinants present in the $\mathrm{Fd}$ region of the whole G3-immunoglobulin molecule.

$\mathrm{Gm}$ testing, kindly performed by Dr. A. Steinberg, showed the $\mathrm{Gm}$ phenotype of this protein to be $\operatorname{Gm}(5,6,-$ $14+)$, but $\operatorname{Gm}(1,2,3,13$, nd $21[-])$, which is consistent with a G3-paraprotein deriving from a Negro individual (13). As expected, the protein was $\operatorname{Inv}(-1)$ and negative for the $\mathrm{Oz}$ (lambda chain) peptides (14). The presence of $\mathrm{Gm}$ factors, and IgG class and subclass antigenic determinants, demonstrate the close relationship of this protein to Fc-fragment of IgG3. Retention of antigenic properties indicates that the $\gamma \mathrm{HCD}$ has maintained structural integrity, lending support to the view that G3-determinants lacking in $\gamma \mathrm{HCD}-\mathrm{JM}$ represent deletion from the molecule.

3. Ultracentrifugation. Purified $\gamma \mathrm{HCD}-\mathrm{JM}$ had an uncorrected sedimentation coefficient of $3.7 \mathrm{~S}$. The sedimentation coefficient of native protein in $4 \mathrm{M}$ urea was $1.7 \mathrm{~S}$, but that of reduced alkylated (RA) protein in urea was about half or $0.8 \mathrm{~S}$. The finding that native and RA protein in saline have similar sedimentation coefficients (3.7 and 3.9S, respectively) indicates that the protein, in the native state, is a dimer held together by noncovalent bonds in addition to disulphide bonds.

4. Peptide maps. Peptide map comparison of the $\gamma \mathrm{HCD}-\mathrm{JM}$ and the Fc-fragment of a G3-myeloma protein showed a great similarity in number and position of peptides (Fig. 3). Minor differences exist that may reflect differences in $\mathrm{Gm}$ factors, as well as slight size differences between the protein of heavy chain disease and the artificially produced $\mathrm{Fc}$-fragment. The similarity of these polypeptide chains is striking, however, and indicates that the $\mathrm{H}$ chain disease protein bears a close structural resemblance to the $\mathrm{Fc} \gamma 3$-fragment.

5. Amino acid analysis. Amino acid analysis of $\gamma \mathrm{HCD}-\mathrm{JM}$ is recorded in Table I. The protein contains 
TABLE I

Amino Acid Composition of $\gamma H C D-J M$

\begin{tabular}{lc}
\hline \multicolumn{1}{c}{ Amino acid } \\
\hline \\
Lysine & $\begin{array}{c}\text { moles of amino acid } / 28,500 \mathrm{~g} \\
\text { of protein }\end{array}$ \\
Histidine & 15.9 \\
Arginine & 5.9 \\
Aspartic Acid & 7.9 \\
Threonine & 20.0 \\
Serine & 19.7 \\
Glutamic Acid & 26.4 \\
Proline & 26.8 \\
Glycine & 25.7 \\
Alanine & 21.6 \\
Half-cystine & 9.3 \\
Valine & 6.6 \\
Methionine & 24.9 \\
Isoleucine & 2.7 \\
Leucine & 3.6 \\
Tyrosine & 19.8 \\
Phenylalanine & 3.9 \\
\end{tabular}

Average of two 24-hr hydrolyses.

* Determined as carboxymethylcysteine.

about 7 moles of carboxymethylcysteine/28,500 $\mathrm{g}$ of protein, which is consistent with the number of inter- and intrachain disulfide bonds present in $\gamma \mathrm{HCD}-\mathrm{Zu}$ and human $\mathrm{Fc}_{\gamma} 3$ (15). The analysis is also consistent with a protein of $56,000-59,000 \mathrm{~mol} \mathrm{wt}$.

6. $\mathrm{NH}_{2}$-Terminal studies. The $\mathrm{NH}_{2}$-terminal amino acid of $\gamma \mathrm{HCD}-\mathrm{JM}$ was glutamic acid and this was obtained in a yield of $66 \%$ by the Stark procedure. Additional amino acids such as serine and threonine were also obtained in low yield ( 9 and $6 \%$, respectively). Similar analysis of $\gamma \mathrm{HCD}-\mathrm{Craw}$ showed that the predominant $N$-terminal residue was glycine, recovered with a $30 \%$ yield. Here other amino acids, aspartic acid $(10 \%)$, glutamic acid $(5 \%)$, leucine $(10 \%)$ and alanine (5\%) were also obtained. The low yields could result from losses during the procedure or from the presence of a blocked $\mathrm{NH}_{2}$ terminus of the proteins.

The $\mathrm{NH}_{2}$-terminal amino acids of $\gamma \mathrm{HCD}-\mathrm{JM}$ and $\gamma \mathrm{HCD}$-Craw were found to be in the open form and not in a blocked, cyclized, pyrollidone carboxylic acid (PCA) form. This was ascertained by digestion of 10 $\mathrm{mg}$ of heat-denatured urinary $\gamma \mathrm{HCD}$ with chymotrypsin and by passing the digest through a Dowex- 50 column. The effluent was collected, and an amino acid analysis performed. The same procedure was used for isolated serum $\gamma \mathrm{HCD}-\mathrm{JM}$ paraprotein. No peptide was obtained for either urinary $\gamma \mathrm{HCD}$ or for serum $\gamma \mathrm{HCD}-\mathrm{JM}$, thus ruling out a blocked amino terminal residue. These findings suggest that the $\mathrm{NH}_{2}$ terminus of $\gamma \mathrm{HCD}-\mathrm{JM}$ and $\gamma \mathrm{HCD}$-Craw are unlike that of most whole heavy chains that generally occur in the cyclized PCA form.

Comparison of the $\mathrm{NH}_{2}$-terminal region of the $\gamma \mathrm{HCD}$ $\mathrm{JM}$ with normal $\gamma$-chains was extended by attempts to isolate an $\mathrm{NH}_{2}$-terminal peptide. Pronase digest of the acetylated $\gamma \mathrm{HCD}-\mathrm{JM}$ was passed twice through a Dowex-50 column and yielded a mixture of peptides that were separated from each other on paper by high voltage electrophoresis at $\mathrm{pH}$ 6.5. All these peptides were detected by a peptide bond stain but they failed to react with ninhydrin. The amino acid compositions and yields of these peptides are shown in Table II. Several explanations exist for the occurrence of this mixture of Pronase peptides. There may be true heterogeniety of the $N$-terminus in the J. M. paraprotein. Alternatively, some of the peptides may have passed through the Dowex column either because they were too acidic to be retained by the resin or because an amino-terminal glutamic acid or glutamine underwent cyclization to the PCA form. In any case, none of the isolated peptides resemble the $N$-terminal sequence of whole $\gamma$-heavy chains obtained in our laboratory (16) or reported elsewhere (17).

\section{(B) Cellular studies}

Biosynthesis. In order to ascertain if the $\gamma \mathrm{HCD}-\mathrm{JM}$ is secreted as a heavy chain fragment, bone marrow cells from the patient were incubated in short-term culture with $1 y \sin -{ }^{14} \mathrm{C}$ and isoleucine $-{ }^{14} \mathrm{C}$. Supernatant fluid was collected, concentrated, and analyzed by radioimmunoelectrophoresis (Fig. 4). A radioactive precipitin arc of fast gamma electrophoretic mobility was detected by using a polyvalent anti-immunoglobulin and specific anti-IgG serum. This arc is not present with anti-kappa or antilambda serums. These studies show that the patient's bone marow contains cells that secrete the $\gamma \mathrm{HCD}$ of this disease. This is direct evidence that $\gamma \mathrm{HCD}$ is not the result of extracellular proteolysis of a whole $\gamma$-heavy chain.

Immunofluorescence. Immunofluorescent tests were performed to determine whether or not the cells synthesizing the $\gamma \mathrm{HCD}$ also synthesized light polypeptide chains. Bone marrow and lymph node of patient J. M. had $7-10 \%$ cells that reacted with anti- $\gamma$-serum but less

TABLE II

Pronase-Dowex Peptides of HCD-JM

\begin{tabular}{cllll}
\hline Peptide & \multicolumn{3}{c}{ Amino acid composition } & Yield \\
\hline 1 & Ser 1.0 & Glu 1.6 & Gly 1.0 & $14.8 \%$ \\
2 & Ser 1 & Glu 1.2 & & $12.6 \%$ \\
3 & Ser 1.3 & Glu 1.2 Pro 1 & Gly 1.1 & $27.5 \%$ \\
4 & Ser 1.4 & Glu 1.8 Pro 1.0 & Gly 1.1 & $17.6 \%$ \\
\hline
\end{tabular}




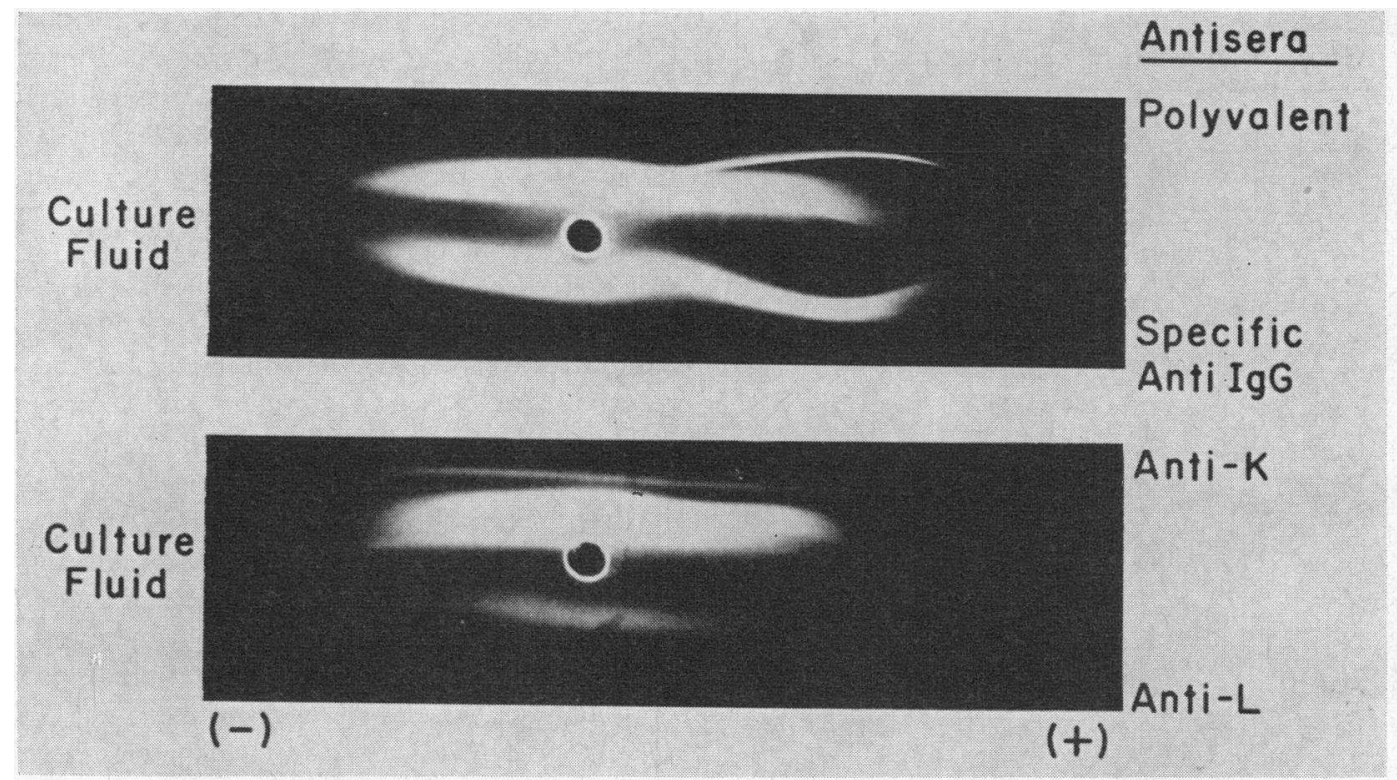

FIGURE 4 Biosynthetic study of heavy chain disease patient's bone marrow cells. Radioimmunoelectrophoresis of the supernatant fluid from short-term culture of these cells demonstrates incorporation of amino acids ${ }^{14} \mathrm{C}$ in $\gamma \mathrm{HCD}$. Normal IgG is also synthesized by a population of cells in this bone marrow. Anti-k and anti-L are antisera specific for kappa and lambda light chains.

than $2 \%$ stained for kappa and lambda light chains (Table III). This relatively much greater stain for heavy chains was not observed in control experiments. Bone marrow from a patient with a serum Waldenström's macroglobulin with lambda light chains (G. B.) showed $34 \%$ of cells staining for $\mu$-heavy chains and about the same percentage (i.e., $31 \%$ ) staining for lambda light

TABLE III

Immunofluorescent Tests of J. M. and Control Tissues

\begin{tabular}{|c|c|c|c|c|}
\hline \multirow[b]{2}{*}{$\begin{array}{l}\text { Fluorescein-conjugated } \\
\text { antiserum against : }\end{array}$} & \multicolumn{2}{|c|}{ J. M. } & \multirow{2}{*}{$\frac{\text { Ben }}{\begin{array}{c}\text { GMP-K } \\
\text { marrow }\end{array}}$} & \multirow{2}{*}{$\frac{\text { G. B }}{\begin{array}{r}\text { Macro-1§ } \\
\text { marrow }\end{array}}$} \\
\hline & $\begin{array}{l}\text { Bone* } \\
\text { marrow }\end{array}$ & $\begin{array}{c}\text { Lymph } \\
\text { node }\end{array}$ & & \\
\hline
\end{tabular}

Heavy chains

$\%$ fluorescent cells $/ 400$ cells counted

$\begin{array}{rllrr}\gamma & 7 & 9 & 17 & 1 \\ \alpha & 0 & 0 & 3 & 3 \\ \mu & 0.5 & 0.2 & 8 & 34\end{array}$

Light chains

\begin{tabular}{rrrrr}
$\kappa$ & 0 & 02 & 16 & 0 \\
$\lambda$ & 0 & 1.2 & 1 & 31 \\
\hline
\end{tabular}

* Data from a single experiment. Duplicate experiments gave very similar results.

‡ GMP-K = IgG-myeloma protein containing kappa light chains.

$\S$ Macro-L = macroglobulin $(\operatorname{Ig} M)$ containing lambda light chains. chains. Similarly, bone marrow from a patient with a G-myeloma protein, with kappa light chains (Ben) showed about the same percentage of cells staining for kappa light chains as for $\gamma$-heavy chains.

Double-labeling experiments were performed with J. M. tissues with various combinations of fluoresceinand rhodamine-conjugated antisera (Table IV). Control experiments performed with bone marrow from a patient with a kappa-type G-myeloma protein revealed that about $90 \%$ of all fluorescent cells showed yellow fluorescence when stained with anti- $\gamma \mathrm{G}$ plus anti-kappa sera (Table IV). When anti- $\gamma \mathrm{G}$ was used with anti- $\lambda$, about $85-95 \%$ of cells showed only the fluorescence expected with the $\gamma$-reagent alone.

Bone marrow from the heavy-chain disease patient showed from 85 to $92 \%$ fluorescent cells staining only for $\gamma$-heavy chains. At most, $14 \%$ of cells showed any evidence of reaction with light-chain antisera. Fluorescence was homogeneous throughout the cytoplasm of cells that appeared plasmacytic. No nuclear fluorescence was observed. These tests with J. M. tissue show that $\gamma \mathrm{HCD}$ is synthesized in the absence of light chains.

Further studies were done to detect human IgG3-containing cells (Table V). Since the IgG3-subclass represents only from 5 to $10 \%$ of serum IgG, it might be expected that from 5 to $10 \%$ of normal IgG-producing cells make IgG3. By contrast, in G3-myeloma and in heavy chain disease (J. M.), most of the plasma cells in the 
TABLE IV

Double-Staining of J. M. and Ben Bone Marrow Cells

\begin{tabular}{|c|c|c|c|c|c|c|}
\hline \multirow[b]{2}{*}{ Observed fluorescence } & \multicolumn{3}{|c|}{ J. M. $(\gamma \mathrm{HCD})$} & \multicolumn{3}{|c|}{ Ben (GMP-K) } \\
\hline & Red & Yellow* & Green & Red & Yellow & Green \\
\hline & \multicolumn{6}{|c|}{$\%$ of all fiurescent cells } \\
\hline \multicolumn{7}{|l|}{ Antisera } \\
\hline Rd anti- $\gamma \ddagger+\mathrm{Fl}$ anti- $\kappa \S$ & 92 & 3 & 5 & 6 & 90 & 4 \\
\hline Rd anti- $\gamma+\mathrm{Fl}$ anti- $\lambda$ & 95 & 5 & 10 & 85 & 4 & 11 \\
\hline $\mathrm{Fl}$ anti- $\gamma+$ Rd anti-k & 2 & 10 & 88 & 7 & 89 & 4 \\
\hline $\mathrm{Fl}$ anti- $\gamma+\mathrm{Rd}$ anti- $\lambda$ & 5 & 5 & 90 & 3 & 2 & 95 \\
\hline
\end{tabular}

* Yellow fluorescence indicates that both reagents are reacting in the same cell.

‡ Rhodamine-conjugated.

$\S$ Fluorescein-conjugated.

patient's bone marrow react with IgG3 immunofluorescent reagents. In the J. M. bone marrow, $67 \%$ of the fluorescent-positive cells contained G3-protein. This figure is in good agreement with the data for light- and heavy-chain-containing cells in Table III. Appropriate controls in the IgG3 tests consisted of bone marrow from a patient with serum G3-myeloma protein and marrow from a patient with diffuse hypergammaglobulinemia (Table V).

\section{DISCUSSION}

The present studies show that by a variety of criteria, the $\gamma \mathrm{HCD}$-JM paraprotein is related to the Fc-fragment of IgG and is, therefore, like other $\mathrm{H}$ chain disease proteins $(1-5,19)$. The occurrence of about half of a $\gamma$-heavy chain in HCD, which is related to the Fc-fragment of IgG, raises important questions about the formation of this paraprotein. The biosynthetic findings in the present study show that the HCD protein is a secreted product of cells present in the patient's bone marrow. This rules out the possibility that extracellular proteolysis of IgG is responsible for the presence of the Fclike-fragment in serum. Franklin, (1) reached the same conclusion by showing a normal survival of $\operatorname{IgG}^{-131} \mathrm{I}$ in the original heavy chain disease patient Craw. Their study, however, does not eliminate the possibility that the disease was characterized by secretion of a type of IgG, normally present in low quantities, which is especially susceptible to proteolysis. Furthermore, studies of the catabolism of the $\mathrm{H}$ chain disease protein show that defective catabolism of the protein is not responsible for its high serum concentration and demonstrate, that the synthetic rate of the protein in J. M. far exceeds that of IgG in normal individuals. ${ }^{3}$

The immunofluorescent findings place additional constraints on any general theory concerning the synthetic origin of this protein. These show that the involved cells do not synthesize light chains, an observation also made by Bloch and Ellman (18). These data indicate that there is a disturbance in the control of normal immunoglobulin synthesis to the extent that structural genes for light chains are not expressed in the involved cells.

A defect must also exist in synthesis of heavy polypeptide chains to account for the secretion of only a portion of the molecule. Franklin (19) has raised the possibility that the $\gamma \mathrm{HCD}$ represents a natural subunit of $\mathrm{H}$ chains approximately corresponding to the Fc-fragment. This would imply that separate genes encode the

\footnotetext{
${ }^{3}$ Ein, D., and T. A. Waldmann. Metabolic studies of a heavy chain disease protein. Submitted for publication.
}

TABLE V

Immunofluorescent Tests with G3-Subclass Specific Antiserum

\begin{tabular}{lccc}
\hline & Antiserum & J. M. $(\gamma \mathrm{HCD}) *$ & $\begin{array}{c}\text { Lis (diffuse hyper- } \\
\text { globulinemia) }\end{array}$ \\
\hline Fl anti-IgG $(\gamma) \ddagger$ & $9 \S$ & 18 & 25 \\
Specific anti-G3\| & 6 & 16 & 5 \\
Per cent G3-reactive cells per total IgG-reactive cells & 67 & 89 & 20 \\
\hline
\end{tabular}

* Washed bone marrow cells were used from each of the three patients.

$\ddagger$ Fluoroscein-conjugated and used in direct method.

\&ata expressed as \% fluorescent cells $/ 400$ cells counted.

$\|$ Used in an indirect method with fluoroscein-conjugated goat anti-rabbit serum. 
Fd and Fc regions of heavy chains. Normally, these two regions are covalently joined by peptide bonds. Furthermore, studies of the synthesis of heavy polypeptide chains, using normal rabbit lymph nodes (20) and mouse plasma cell tumors (21), suggest that heavy chains are synthesized as a single unit from amino to carboxyl terminus. There is no indication for the separate synthesis of $\mathrm{Fd}$ and $\mathrm{Fc}$ portions of normal or myeloma $\gamma$-heavy chains. Any union of the information of the $\mathrm{Fd}$ and $\mathrm{Fc}$ regions, therefore, would normally have to be done at the DNA or mRNA level. If the heavy chain disease protein represented expression of an Fc gene, the occurrence of this protein would reflect a defect existing in normally coordinate expression of $\mathrm{Fd}$ and $\mathrm{Fc}$ genes.

There are other possible explanations for the occurrence of only half of a heavy chain in this disease. For example, it has been suggested (22) that a mutation may occur to a chain initiating codon, somewhere in the middle of the $\mathrm{H}$ chain cistron.

Another mechanism has been proposed by Prahl (23) who has suggested that in $\mathrm{H}$ chain disease, chain synthesis is initiated in a normal manner for whole $\mathrm{H}$ chain but that there is a large gene deletion in the $\mathrm{Fd}$ region. This suggestion arose from observations of the $\mathrm{N}$-termimal tripeptide of $\gamma \mathrm{HCD}-\mathrm{Zu}$ which has the sequence Glp-Val-Thr. This sequence is identical to the predominant $N$-terminal sequence of pooled human IgG heavy chains (17). Our data in contrast, show that $\gamma \mathrm{HCD}-\mathrm{JM}$ and $\gamma \mathrm{HCD}$-Craw differ at the $\mathrm{NH}_{2}$-terminal amino acid from normal $\gamma$-polypeptide chains, having predominantly glutamic acid and glycine, respectively. Also, our data indicates that $\gamma \mathrm{HCD}-\mathrm{JM}$ does not contain peptides resembling the reported $N$-terminal peptides of pooled $\gamma$-heavy chains (17) or $\mathrm{H}$ chains of G-myeloma proteins $(16,17)$. These data do not fit the hypothesis of deletion within the $\gamma$-polypeptide chain but indicate rather that the $N$-terminal portion of the normal chain is missing.

The observed heterogeneity of the $\mathrm{N}$-terminus is consistent with the hypothesis that intracellular proteolysis cleaves the nascent heavy chain in the $\mathrm{Fd}$ region. It could be that heavy chains unprotected by light chains are sensitive to intracellular enzymes. The Fc-fragment might not be effected and presumably might be secreted from the cell. Using an absorbed antiserum (Fig. 2 c), an attempt was made to demonstrate $\mathrm{Fd}$ determinants in the J. M. tumor cells by immunofluorescence. Although some cells showed positive staining, this antiserum is not strictly specific for the Fd region. Since it has not been possible to exclude the possibility that Fd-fragments are also being made, it is important that they be sought in the future.

Two types of studies could test the proposed models.
Recent studies of the synthesis and assembly of immunoglobulin molecules have shown that heavy and light chains are synthesized on polysomes of different sizes $(22,24)$. The identification of the size of polysomes responsible for $\mathrm{H}$ chain disease protein manufacture would indicate whether the whole or only part of the $\mathrm{H}$ chain was being synthesized. The size of the polysomes would presumably be independent of whether or not intracellular proteolytic enzymes cleaved an intact $\mathrm{H}$ chain. Secondly, it might be possible to determine the size of newly synthesized intracellular protein after a short pulse of radioactive amino acids followed by inhibition of all enzyme activity. ${ }^{4}$

Because of limitations in available J. M. tissue, these experiments could not be carried out. It is to be hoped that this kind of study will be feasible when another case of heavy chain disease is discovered so that definite information about the origin of this protein may be obtained.

\section{ACKNOWLEDGMENTS}

The authors wish to thank Dr. Zbigniew Zawadzki for having referred this patient to us, Dr. William Terry for generous donations of time and reagents, and Dr. Leroy Hood for determining the $N$-terminal amino acid and for his helpful advice. Dr. E. C. Franklin provided generous quantities of the $\gamma \mathrm{HCD}$-Craw for $N$-terminal analysis. We are grateful to Mrs. Diane Pincus, Mrs. Kathleen Cotter Conn, Mrs. Helen Grimes, Miss Joyce Ellis, and Mr. Matthew Miller for their competent technical assistance.

\section{REFERENCES}

1. Franklin, E. C., J. Loweustein, B. Bigelow, and M. Meltizer. 1964. Heavy chain disease-a new disorder of serum $\gamma$-globulins. Report of the first case. Amer. J. Med. $37: 332$.

2. Osserman, E. F., and K. Takatsuki. 1964. Clinical and immunochemical studies of four cases of heavy $(\mathrm{H} \gamma 2)$ chain disease. Amer. J. Med. 37: 351 .

3. Lebreton, J. P., C. Rivat, L. Rivat, L. Guillemot, and C. Ropartz. 1967. Une immunoglobulinopathie meconnue: la maladie des chaine lourdes. La Presse Medicale. 75: 2251.

4. Ellman, L. L., and K. J. Bloch. 1968. Heavy chain disease: report of a seventh case. N. Engl. J. Med. 278: 1195.

5. Piggot, P. J., and E. M. Press. 1967. Cyanogen bromide cleavage and partial sequence of the heavy chain of a pathological immunoglobulin G. Biochem. J. 104: 616.

6. Fahey, J. L., and C. McLaughlin. 1963. Preparation of antisera for $6.6 \mathrm{~S}$ gamma-globulins, $\mathrm{B}_{2 \mathrm{~A}}$-globulins,

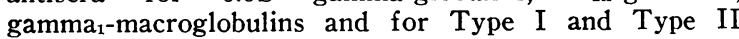
common gamma-globulin determinants. J. Immunol. 91 : 484.

7. Appella, E., and D. Ein. 1967. Two types of lambda polypeptide chains in human immunoglobulins based on an amino acid substitution at position 190. Proc. Nat. Acad. Sci. 57: 1449 .

${ }^{4}$ Scharff, M. Personal communication. 
8. Finegold, I., J. L. Fahey, and T. Dutcher. 1968. Immunofluorescent studies of immunoglobulins in human lymphoid cells in continuous culture. J. Immunol. 101: 366.

9. Hochwald, G. M., G. J. Thorbecke, and R. Asofsky. 1961. Sites of formation of immune globulins and of a component of $\mathrm{C}^{\prime} 3$. A new technique for the demonstration of the synthesis of individual serum proteins by tissues in vitro. J. Exp. Med. 114: 459.

10. Sanders, J. H., J. L. Fahey, I. Finegold, D. Ein, R. Reisfeld, and C. Berard. 1968. Multiple anomalous immunoglobulins: clinical, structural and cellular studies in three patients. Amer. J. Med. In press.

11. Stark, G. R. 1967. Use of cyanate for determining $\mathrm{NH}_{2}$ terminal residues in proteins. In Methods in Enzymology. C. H. W. Hirs, editor. Academic Press Inc., New York. $11: 125$.

12. Terry, W. D., and J. L. Fahey. 1964. Subclasses of human $\boldsymbol{\gamma}_{\mathbf{2}}$-globulin based on differences in the heavy polypeptide chains. Science. 146: 400.

13. Terry, W. D., J. L. Fahey, and A. G. Steinberg. 1965. $\mathrm{Gm}$ and Inv factors in subclasses of human IgG. J. Exp. Med. 122: 1087.

14. Ein, D. 1968. Nonallelic behavior of the $\mathrm{Oz}$ groups in human lambda immunoglobulin chains. Proc. Nat. Acad. Sci. 60: 982

15. Frangione, B., and C. Milstein. 1968. Variations in the $\mathrm{S}-\mathrm{S}$ bridges of immunoglobulin $\mathrm{G}$ : interchain disulphide bridges of $\gamma \mathrm{G} 3$ myeloma proteins. J. Mol. Biol. 33: 893.
16. Terry, W., and H. Metzger. 1968. Studies of human immunoglobulin heavy chains: $N$-terminal sequences. Fed. Proc. 27: 559.

17. Porter, R. R., and E. M. Press. 1965. $N$-terminal peptide of the heavy chain of immunoglobulin IgG. Biochem. J. 97: 32P. (Abstr.)

18. Bloch, K. J., and L. L. Ellman. 1968. Heavy chain (Fc fragment) disease: report of an additional case with further evidence for the synthesis of a fragment of $\gamma$ G-globulin. J. Clin. Invest. 47: 8 a. (Abstr.)

19. Franklin, E. C. 1964. Structural studies of human $7 \mathrm{~S} \gamma-$ globulin (G-immunoglobulin). Further observations of a naturally occurring protein related to the crystallizable (fast) fragment. J. Exp. Med. 120: 691.

20. Fleischman, J. B. 1967. Synthesis of the $\gamma \mathrm{G}$ heavy chain in rabbit lymph node cells. Biochemistry. 6: 1311 .

21. Knopf, P. M., R. M. E. Parkhouse, and E. S. Lennox. 1967. Biosynthetic units of an immunoglobulin heavy chain. Proc. Nat. Acad. Sci. 58: 2288.

22. Askonas, B. A., and A. R. Williamson. 1966. Biosynthesis of immunoglobulins on polyribosomes and assembly of the IgG molecule. Proc. Roy. Soc. Ser. B. 166: 232.

23. Prahl, J. W. 1967. $N$ - and $C$-terminal sequences of a heavy chain disease protein and its genetic implications. Nature (London). 215: 1386.

24. Scharff, M. D., and J. W. Uhr. 1965. Functional ribosomal unit of gamma-globulin synthesis. Science. 148: 646. 